International Journal of Child, Youth and Family Studies (2019) 10(1): 49-69

DOI: $10.18357 /$ ijcyfs 101201918806

\title{
RESPONSES TO ADVERSITY FACED BY FARMING MEN: A GENDER-TRANSFORMATIVE ANALYSIS
}

\author{
Philippe Roy, Émilie Duplessis-Brochu, and Gilles Tremblay
}

\begin{abstract}
The values that characterize the traditional and stereotypical image of rural masculinity put pressure on farming men to engage with risky behaviours, both physical and mental, and reduce their willingness to seek help. This paper investigates individual and social responses to adversity, under the lenses of response-based practice and gender-transformative health promotion. Our method is based on qualitative semi-structured interviews with 32 farming men and 2 focus group interviews with 14 experts on men's health, farming, and rural social work. Results suggest gender is negotiated through individual and social responses to adversity, with fluid transitions between conformity and resistance with regard to traditional masculinity. Individual responses to adversity can include negative or positive coping strategies. Social responses can be supportive, or they can be marginalizing, such as the devaluation of farming. For farmers facing adversity, there is a disparity in social support, with communal solidarity being evident in a material crisis, but not in a personal one. Some community-based responses are highlighted for their ability to support farming men in coping with adversity.
\end{abstract}

Keywords: gender, masculinities, men's health, social responses, rural, farmers

Acknowledgements: Authors are thankful to participants and colleagues who shared their experience and expertise and made this study possible. Financial support was provided by the Canadian Institutes of Health Research (Institute of Gender \& Health, and Public Health and the Agricultural Rural Ecosystem); Fonds Québécois de recherche sur la société et la culture; Masculinities and Society research team; Fondation Desjardins; and the Faculty of Social Sciences at Université Laval. Additional gratitude is expressed to Catherine Richardson/Kinewesquao and the organizing committee of the Responses Matter conference for the opportunity to develop and share the content of this paper.

Philippe Roy PhD (corresponding author) is Associate Professor and Lecturer in Social Work at Université du Quebec à Chicoutimi, 555 boulevard de l'Université, room H4-1080, Chicoutimi, QC G7H 2B1. Email: Philippe1_roy@uqac.ca

Émilie Duplessis-Brochu LLB, MSc is a graduated Master's student at the School of Social Work, Université de Montreal, Pavillon Lionel-Groulx, 3150 rue Jean-Brillant, Montreal QC H3T 1N8. Email: emilie.duplessis.brochu@umontreal.ca 
International Journal of Child, Youth and Family Studies (2019) 10(1): 49-69

Gilles Tremblay $\mathrm{PhD}$ is a professor in the School of Social Work and Criminology at Laval University, Pavillon Charles-De Koninck, 1030 avenue des Sciences-Humaines, Bureau DKN5444, Quebec City, QC G1V 0A6. Email: Gilles.Tremblay@tsc.ulaval.ca 
International Journal of Child, Youth and Family Studies (2019) 10(1): 49-69

"Men have no emotion and farmers even less. We're not supposed to", said Gabriel sarcastically. The tough-looking farmer was speaking about his motivation for taking a few hours out of his very busy schedule to participate in a study on farming men's experiences of stress and their ways of coping. This statement resonates with a growing body of media coverage and academic literature exploring connections between masculinities and mental health in the context of farming men facing adversity - excessive financial pressure, increasing work overload, family-work strains, lack of social recognition, and so on (Alston, 2012; Garnham \& Bryant, 2014; Sturgeon \& Morrissette, 2010). New ways to investigate the issue emerge by combining responsebased practice (Richardson \& Wade, 2016) and gender-transformative health promotion (Barker, Ricardo, Nascimento, Olukoya, \& Santos, 2010; Tannenbaum, Greaves, \& Graham, 2016). Response-based practice pays attention to the actions by which individuals and communities respond to adversity and oppression (Coates, 2016; Richardson \& Wade, 2016). For example, when farming men experience depression, their work colleagues may react by telling them to "stop whining, take it like a man, and go back to work", causing possible shame and social withdrawal, in addition to the initial symptoms of depression. The quality of social response is crucial because it can either support resistance to oppression and adversity, or exacerbate those forces, inflicting additional burden or trauma. Gender-transformative health promotion is a framework that seeks to question and transform restrictive gender norms and to promote more gender-equal relationships between individuals (Barker et al., 2010).

This paper aims to highlight farming men's adversity as a serious social issue, and to offer new perspectives on social and individual responses to adversity that mainly involve negotiating "masculinities" - gender identities aligned in conformity or resistance to traditional masculine ideology (Levant \& Habben, 2003; Pleck, 1995; Robertson, 2008). The term "masculinities" is understood as denoting socially constructed configurations of social practices that are fluid, situational, and sometimes contradictory (Connell \& Messerschmidt, 2005; Gough, 2013; Robertson, 2008). The sections below detail concepts of rural and farming masculinities, followed by their implications with regard to farming men facing adversity.

\section{Background}

\section{Challenges and Adversity in Farming Context}

Farmers of all genders are likely to face adversity at the family and business level — farms are often family businesses - as well as the social and political levels. Farm-related stressors include long working hours and the concomitant pressure on family-work balance, conflicts with farming and non-farming rural residents, an increasing burden of legislation and paperwork, dependence on weather, climate change, financial pressure, and the increasing complexity of farmrelated business (Canadian Agricultural Safety Association, 2005; Haggerty, Campbell, \& Morris, 2009; Magnin et al., 2017; Sturgeon \& Morrissette, 2010). Additionally, knowledge related to 
International Journal of Child, Youth and Family Studies (2019) 10(1): 49-69

mechanics, biology, genetics, and computers - all necessary for modern agriculture — is increasingly complex (Lafleur \& Allard, 2006).

Many farmers feel that their profession is criticized and devalued, and that their lifestyle is marginalized (Droz, Miéville-Ott, Jacques-Jouvenot, \& Lafleur, 2014; Jacques-Jouvenot \& Laplante, 2009); they demand better social acknowledgement (Parent, Perrier, \& Rousseau, 2010). Farmers are affronted by negative views; this is well documented in media coverage of farmers' public advocacy and protests reporting slogans such as "No farmers no food" (K. Boisvert, 2009) and "We feed you but we die" (Lamothe, 2016). Farming is considered one of the most stressful occupations (Canadian Agricultural Safety Association, 2005); this is not surprising given the adversity farmers face and the negative views they encounter.

\section{Farming Men's Mental Health from a Gender Perspective}

Studies on responses to adversity among farming men have pointed out that masculinities can have either a positive or negative impact. The literature on rural men's health is consistent in maintaining that traditional and stereotypical ideals of rural masculinities are built on values of independence, stoicism, self-sufficiency, pride, strength, competition, relentless work, and economic success (Courtenay, 2006; Fraser et al., 2005; Garnham \& Bryant, 2014; Kennedy, Maple, McKay, \& Brumby, 2014; Robertson, Elder, \& Coombs, 2010; Roy, Tremblay, Oliffe, Jbilou, \& Robertson, 2013). Such agrarian values shape rural masculinities grounded in extreme resourcefulness (excessive autonomy and self-reliance) and endurance through adversity. The pressure to live up to these stereotypical expectations constitutes a double risk for farming men as it pressures them to engage in risky behaviours — both physical and mental — and deters farming men from seeking help (Creighton, Oliffe, Ogrodniczuk, \& Frank, 2017; Kennedy et al., 2014; Sturgeon \& Morrissette, 2010). Farmers who align more rigidly with traditional masculinity are prone to stoically deny mental health problems or endure pain until it reaches a critical point (Judd et al., 2006; Roy et al., 2013; Sturgeon \& Morrissette, 2010). It is theorized that traditional masculine practices appeal to farming men due to their professional insecurity, relatively low education, and low political power (Campbell, Mayerfeld Bell, \& Finney, 2006). Compared to non-farming rural and urban men, farming men are more likely to experience accidents, both fatal and non-fatal; high levels of psychological distress; suicidal ideation; and mortality (Alston, 2012; Garnham \& Bryant, 2014; Kennedy et al., 2014; Prévitali, 2015; Roy et al., 2013). However, this international trend was not found in rural China, where women had higher suicide rates than men up to 2005, but have had lower rates since then (Wang, Chan, \& Yip, 2014). Among farming women in rural China, risk factors include discrimination and oppression (Qin, Jin, Zhan, Yu, \& Huang, 2016). Thus, the situation is complex and gender appears to be a key element for investigation and advocacy.

Across Australia, New Zealand, India, North America, and Europe, many farmers' unions

and associations raise awareness about the adversity faced by farming communities. In most media reports and academic work, a strong focus remains on "problem-describing" (Bourke, Humphreys, 
International Journal of Child, Youth and Family Studies (2019) 10(1): 49-69

Wakerman, \& Taylor, 2010). While this is a crucial step, it seems little is known yet about current social and individual responses to adversity faced by farming men. Moreover, since gender is known to be a major social determinant of health, these responses are likely to be influenced by masculinities intersecting with occupation (farming) and place (rural). To be able to explore the role gender plays in farming men's responses to adversity, it is necessary to describe both individual and social responses with gender-transformative and response-based approaches.

\section{Methodology}

\section{Data Collection}

At an early stage of the research process, the first author began field work with an exploratory phase based on 10 discussions with key informants including doctors, social workers, and community services staff in rural areas across the Province of Quebec, Canada. The first author also spent a day on a farm with a farming couple involved in community-based suicide prevention. These activities were important for gaining a better knowledge of the farming ecosystem and to locate the research in its context. Recruitment was done with the collaboration of farming unions, mental health community services, and key informants. Posters were distributed through social media and through newsletters (by email). Potential participants were invited to contact the research team by email or phone. The initial contact answered the respondent's questions about the study and scheduled a time and place for the interview.

Thirty-two farming men agreed to take part in semi-structured interviews. Participants had the choice of place for the interviews. Most of the interviews (29) took place at the participant's home or farm (in most cases, these were the same location). Two interviews were conducted by phone and one took place at a university near the participant's home. When the first author arrived at a participant's home, he would ask for a guided tour of the farm. Beyond his personal curiosity and interest in farming, the purpose of this request was to build rapport with the participant in a casual, non-hierarchical, conversational interview. It is widely acknowledged farmers are passionate about their farming. Thus, the farm tour enabled the first author to demonstrate genuine interest in the participant's passion and pride in farming: business, animals, land, home, and family. This is consistent with the research interview as a practice of masculinity with a wide range of meanings that could occur, such as taking control of the interview, emphasizing stoicism, or emotional disclosing (Oliffe \& Mroz, 2005). Particular attention was paid before, during, and after the interviews (i.e., during results dissemination) to positioning participants as experts of their lives. After the farm tour, ethical protocols were explained to all participants and consent forms were reviewed and signed, with a copy provided to each participant. Ethical protocols included strategies in case of emotional distress (which did not occur).

The semi-structured interviews lasted on average 120 minutes. Interviews were audiorecorded and transcribed for data analysis with NVivo qualitative data analysis software. Openend questions were used, with the aim of having participants begin a discussion on farming life, 
masculinities (usually in relation to their social role as father, son, partner, friend, or worker), adversity in farming, and their responses to it. A debriefing was systematically done to get participants' impressions of the interview and assure their well-being; a list of psychosocial resources was provided to all participants at the end of each interview.

Table 1 Farming Men's Sociodemographic Data and Background

\begin{tabular}{|c|c|c|}
\hline Attribute & $n$ & $\%$ \\
\hline \multicolumn{3}{|l|}{ Age groups } \\
\hline $25-34$ & 5 & $16 \%$ \\
\hline $35-44$ & 10 & $31 \%$ \\
\hline $45-54$ & 7 & $22 \%$ \\
\hline $55-65$ & 10 & $31 \%$ \\
\hline \multicolumn{3}{|l|}{ Marital status } \\
\hline Married / In a relationship & 19 & $59 \%$ \\
\hline Divorced / Separated & 12 & $38 \%$ \\
\hline Single & 1 & $3 \%$ \\
\hline \multicolumn{3}{|l|}{ Children } \\
\hline None & 3 & $9 \%$ \\
\hline One & 1 & $3 \%$ \\
\hline Two & 12 & $38 \%$ \\
\hline Three & 11 & $34 \%$ \\
\hline Four and more & 5 & $16 \%$ \\
\hline \multicolumn{3}{|l|}{ Education } \\
\hline Unfinished high school & 2 & $6 \%$ \\
\hline Professional diploma (high school) & 7 & $22 \%$ \\
\hline College & 16 & $50 \%$ \\
\hline University & 5 & $16 \%$ \\
\hline Missing data & 2 & $6 \%$ \\
\hline \multicolumn{3}{|l|}{ Productions } \\
\hline Dairy & 12 & $38 \%$ \\
\hline Mixed productions (poultry, pig, grain, dairy, maple) & 10 & $31 \%$ \\
\hline Lamb & 3 & $9 \%$ \\
\hline Wine & 3 & $9 \%$ \\
\hline Pig & 1 & $3 \%$ \\
\hline Grain & 1 & $3 \%$ \\
\hline Maple & 1 & $3 \%$ \\
\hline Fruits and vegetables & 1 & $3 \%$ \\
\hline \multicolumn{3}{|l|}{ Agriculture type } \\
\hline Conventionnal & 27 & $84 \%$ \\
\hline Organic & 5 & $16 \%$ \\
\hline Total & 32 & $100 \%$ \\
\hline
\end{tabular}




\section{Sample Details}

A total of 44 individuals took part in this study. Individual interviews were done with 32 farming men; 14 practitioners and researchers participated in two focus groups with 6 and 8 people respectively. These focus groups were formed to comment on the farmers' interviews and shed light on outcomes for research and practice. Participants were personally invited based on their experience with farming, rural social work, or men's mental health. Farming men's sociodemographic details are provided in Table 1; participant details are in Table 2.

Table 2 Participants' Attributes

\begin{tabular}{lll}
\hline Attribute & $n$ & $\%$ \\
\hline Gender & & \\
$\quad$ Woman & 8 & $57 \%$ \\
$\quad$ Man & 6 & $43 \%$ \\
Background & & \\
$\quad$ Men's mental health researchers & 5 & $36 \%$ \\
$\quad$ Rural mental health workers & 3 & $21 \%$ \\
$\quad$ Farmers and mental health workers & 2 & $14 \%$ \\
$\quad$ Graduate students & 2 & $14 \%$ \\
Farmers' union advisor and farmer & 1 & $7 \%$ \\
$\quad$ Public health advisor & 1 & $7 \%$ \\
Total & 14 & $100 \%$ \\
\hline
\end{tabular}

\section{Analysis}

Analysis started after the first interview, in line with the general inductive approach (Thomas, 2006). Saturation was gradually obtained halfway (interview 15 of 32) when new analytical categories decreased and existing categories were growing. Initial coding was closely aligned with the interview guide's themes and questions. Main themes were developed and these are discussed in the following section. Repeated readings with the research question in mind enabled the addition of theoretically relevant coding layers. Specific attention was devoted to position in and movement towards or against traditional masculine ideology among participants and within each participant's discourse. Given the nature of semi-structured interviews, data were assumed to be co-constructed by interviewer and participant (Savoie-Zajc, 2003). The interviewer raised awareness about his self-location regarding gender practices, social position, and background (Caucasian, self-identifying as masculine, coming from and currently living in an urban area, pursuing doctorate studies). Reflexivity about self-location was important to assure horizontal, non-hierarchical relationships between interviewer and interviewees. 
International Journal of Child, Youth and Family Studies (2019) 10(1): 49-69

\section{Results $^{1}$}

\section{Farmers' Discourse on Masculinities}

Farming men's discourse is presented as follows: traditional masculinity is used as a reference point based on which results are positioned on a continuum between conformity and resistance (Robertson, 2008). Between those poles is a space for ambivalence and questioning. All participants were aware of the stereotype of the farmer as embodying a traditional masculinity expressed mainly by pride in hard, physical, relentless work.

The father of a large family (more than four children), Yvon ran a dairy farm in a remote town in Quebec. When giving a tour of the farm, he showed great pride in the technological improvements he had made recently. He explained that the man's place is outside the house and the woman's place is inside. This vision was consistent with his lived reality in which he worked outside on the farm and his wife was a stay-at-home mother doing the domestic work inside the home. His discourse was most closely aligned with traditional masculinity when it came to sharing his vision of farming men. Popular role models on $\mathrm{TV}^{2}$ brought him to question his embodiment of traditional masculinity in local practices (in everyday life):

Farmers are machines, work all the time, relentlessly and it's a pride to work hard like this. You can't be a wimp. If you are sick you work anyways. It's different with the younger generation, they want quality of life, work less hours ... I thought showing emotion was showing weakness. Maybe I shouldn't see it this way. Society changes, on TV men are not the same any more, they cry now. It's questioning. Being a tough man, stoic, a real guy, is this good or not? (Yvon)

Yvon's discourse mostly conforms with traditional masculinity, but his questioning can be interpreted as the precontemplation of more open masculinities. Further in the interview, he explained that the ideal man displays a balance between no emotional control and complete stoicism. When facing tough times on the farm, he turned to his children for a hug to wipe away his negative mindset and restore his good mood. Responding to adversity by connecting with his family for emotional support suggests a distance with traditional masculinity. Thus, Yvon demonstrated movement along the masculinities continuum from conformity towards ambivalence.

Most participants' discourse stands in the ambivalence/questioning zone of the continuum. Division of labour between partners is a domain in which participants are able to position and

\footnotetext{
${ }^{1}$ This article is based on a paper presented at the Responses Matter conference in Montreal, Canada, May 18, 2016. Three of the quotes in this section have been published previously (see Roy \& Tremblay, 2015; Roy, Tremblay, Robertson, \& Houle, 2015). They are included here to support the description and discussion of the results.

2 The participant did not discuss any specific role models on TV. For a gender analysis of masculine role models on TV (United States, Canada, and Quebec), see S. Boisvert (2017).
} 
navigate masculinities. Maxime runs a lamb farm in a beautiful, remote village. Married, and the father of teenage boys, this broad-shoulder farmer questioned his practices as a husband and father:

In the house, I'm a big zero. I don't initiate any household chores if I am not told to and it's not OK. I should have been a better model to my boys. Well, a few years back, when the boys didn't clean their rooms, I was doing it after them. I did a bit here and there. My wife has always been more active to support me in the farm than me supporting her in the house and I blame myself for this. In today's society, my boys will be handicapped like their father if they don't take responsibilities in the house. They are going to meet a girl and she won't be there to wipe after them for [swear] sake. It's equal now and it's all right. (Maxime)

He severely criticized his lack of involvement in the household and his negative impact as a role model to his sons. Few other participants disclosed such self-blame for perpetrating an unequal division of labour in and out of the house. Socialization based on traditional masculinity trains men to stay away from household chores. But this trend is countered by new generational ideals and by farmers' emphasis on being autonomous and resourceful.

In regard to emotional disclosure, there was consensus among participants that complete stoicism is not ideal and may lead to violent outbursts. Participants assumed men should be able to control whether they disclose their emotions or not depending on the situation. Some participants openly demonstrated resistance towards traditional masculinity as embodied by other farmers, their fathers, and, more generally, men from previous generations. Roy, Tremblay, and Robertson (2015) provided an illustrative example:

For instance, Pascal, a divorced farmer in his early forties, was open about his consultation with a psychologist following his divorce. He reflected on a media report he had recently seen stating that farmers face more stress than the general population and are less likely to seek help for this:

My relation with help-seeking is influenced by my environment: my friends are not all farmers, I attended school in the city, and my girlfriend is from the city. This non-farming environment surely influenced me because I don't recognize myself among many other farmers who value a certain mentality ... redneck, stubborn, close-minded, we work, we work. But not every farmer is like this. People involved in the farmers' union are more open-minded. (Pascal)

Pascal's discourse represents a view shared by many participants, who showed pride in distancing themselves from traditional farming mentality.

Such was the case of Bernard, a man in his early forties who ran a large farm with diverse livestock. Years before, in a short period of time, he had faced many stressful events: a major accident, a 
International Journal of Child, Youth and Family Studies (2019) 10(1): 49-69

divorce, and his farm going down in flames. Through this adversity, he learned a lot about himself and about masculinities. He was proud of the road travelled since then with the help of men's support groups he participated in:

I used to be a part of the traditional masculine mold when I started working with my parents. I feel manlier now to build my own identity. We (men) got to be more sentimental sometimes. My girlfriend says I am too much emotional, that I am the girl and she's the guy but I am that kind of man. We should not be afraid to roll back our sleeves and assume who we really are. (Bernard)

This quotation from Bernard discloses the social embeddedness of an ideal masculinity and how others maintain it, in this case his girlfriend. Many participants expressed their disconnection with the stereotypical farming mentality and their pride in engaging in a form of masculinity that legitimized their emotional disclosure. Out of the 32 participants, 14 sought professional psychological help. These men were more likely to acknowledge their full range of emotions and their connections with family and friends beyond the strict provider and protector role associated with traditional masculinity. Some even suggested that the human aspect of farming should be studied in farming schools. This vision was more commonly disclosed among younger farmers, those below 50 years of age, the mean age of farmers in Canada (Beaulieu, 2015). Both focus group discussions highlighted that younger farmers were critical of their elders who put so much value on doing relentless work. To the contrary, younger farmers tended to value a balanced life between work, family, and friends.

Sexual orientation as a theme was brought up few times by participants, such as Isaac. He was openly gay, something his friends, family, and broader community were aware of. Isaac explained that he always knew he was gay. At the beginning of adulthood, he was "in the closet", he said, and had to move to a larger city, known for its gay village, to experiment with his sexuality. Back home, he disclosed being gay to his parents and friends who responded with open arms. He did not face discrimination for being gay, but for something else:

With my closest male friends, we give each other kisses and I never have been discriminated, never lost any friend.... I get picked on a lot more often because I run an organic farm than because I am gay. That's a fact. Being organic shakes conservative farmers' beliefs. (Isaac)

This comment echoes the views of a few other participants who, when discussing masculinities, insisted that being gay was no big deal for them. According to Isaac, he was more discriminated against for running an organic farm than for being gay.

Thus, gender ideals and practices were spread out on the continuum between conformity and resistance towards traditional masculinity. Fluidity was also observed as some farming men disclosed different alignments depending on the situation. This dynamic was echoed in the social 
International Journal of Child, Youth and Family Studies (2019) 10(1): 49-69

practices used to face adversity. In the next sections, individual and family responses are presented first, followed by social responses.

\section{Individual Responses to Adversity}

On the individual level, participants experiencing adversity described engaging in negative and positive strategies. Negative strategies included denying symptoms of stress, social withdrawal, excessive investment in work, and contemplating suicide; positive strategies included engaging in self-help actions such as taking work breaks, doing sports, and visiting self-help websites. They could also seek support from family, friends, and professionals, such as doctors, psychologists, or social workers. The story of Jocelyn is salient in this regard. This farmer in his mid-fifties took pride in his physical strength despite his skinny physical appearance, which he used to make an analogy with his resilience against adversity. In the year before the interview, his dairy cows were ill and he was not allowed to sell the milk:

It took a while before I realized it was a depression. I didn't have regular hours for work, sleep, and rest. I could milk the cows at odd hours, sometimes once a day. I could have washed myself and changed my clothes once a week. I saw that I was sick but I thought I could solve it on my own. Then I thought about killing myself. (Jocelyn)

The contemplation of suicide as a means to solve farming-related problems was brought up by five other participants. All of the participants could identify one or more farmers who killed themselves. Jocelyn was very isolated, disconnected from his ex-wife, children, and the wider local community. The negative coping behaviours began to decrease as he remembered the trauma he had experienced when he discovered the body of his neighbour who had completed suicide. Then he began to contemplate reasons to live and positive coping strategies:

I thought suicide would end all my problems. But it leaves a big one. I have found my neighbour's body after a completed suicide. And another neighbour also killed himself. I realize now, I lived for my cows around me. During the Christmas holidays, I called a psychologist I used to see. She was aware I was alone for the holidays and she referred me to a crisis center [temporary shelter]. From there, I was connected with local health services and reached out to an old friend of mine. (Jocelyn)

Jocelyn's coping trajectory could be depicted as a "U" shape, in which the initial phase was, in his words, a "vicious circle", with increasing depression as he engaged in excessive work and contemplated suicide. These strategies are aligned with traditional masculinity's values of relentless work and norms of stoicism and radical behaviour. Hitting rock bottom gave him the impetus to seek other positive coping strategies such as connecting both with his herd and with a friend, and seeking professional help. He greatly appreciated the practitioner he met with for her calm, peaceful attitude and her ability to present a positive outlook. 
International Journal of Child, Youth and Family Studies (2019) 10(1): 49-69

Jocelyn's story is unique among participants because he strongly conformed to traditional masculinity, and then distanced himself from this alignment, and eventually enjoyed his connection with a friend and a professional.

In sum, farming men resist adversity by negotiating health behaviours according to their alignment with traditional masculinity. Conforming with traditional masculinity means facing adversity with silence, denial of distress, social withdrawal, and overinvestment in work; resisting such conformity increases the social acceptability of engaging in healthy behaviours and seeking support from family, friends, and professionals. Engaging with others was described as a crucial part of recovery by a wide majority of participants. While there is ongoing questioning about what farming men do individually to face adversity, the importance they put on social support suggests how much social responses matter.

\section{Social Responses to Adversity}

Solidary movements and gestures have arisen to address adversity faced by farmers, although many gaps remain in terms of social responses. This section presents social responses on the social, political, and community levels. Many participants denounced the devaluation of farming nowadays as imposing a double burden. Producing food for the population is extremely demanding, even exhausting, and farmers often feel marginalized by a part of the population. It is difficult to feel noble about working hard to feed people when those very people stigmatize farming and farmers, accusing them of living off state grants and having unethical farming practices in terms of animal rights and the environment. Also, farming activities sometimes clash with "neo-rural" dwellers (newcomers) looking for quiet time in the countryside. Denis had faced many periods of adversity across his lifetime as a farmer. This 50-year-old man discussed the evolution of social representation of farmers:

Back in the day, we felt supported by the people, by the Department of Agriculture, with policies and promotion. My dad used to work happy, not stressed like nowadays. We felt we had a role to play ... until we became considered as less than prison inmates, less than people on the welfare, and I have nothing against them [prison inmates and people on welfare]. (Denis)

His story highlights the devaluation of farming in society, a position echoed by many participants. Denis pushed forward with this theme, connecting misrepresentations of farming with the acute adversity he once faced:

People think we're rich because they see the machinery. They don't understand, nobody can bear this [financial] pressure. Most people don't pay to work, we do. It costs us everything we have. And this brought my first depression, wandering under the barn's beam to hang myself. It was horrifying, I haven't seen it coming. Just like a flu. My wife didn't see anything. (Denis) 
International Journal of Child, Youth and Family Studies (2019) 10(1): 49-69

To reduce suicide contemplation, Denis called his brother saying everything is messed up, he "sees black". Ten minutes later, a community practitioner phoned Denis, who burst into tears. His brother rushed to Denis to provide support and so did his parents. This discourse exemplifies the adversity of farmers' double burden of work that is demanding yet unacknowledged, and the consequence of this double burden on farmers' mental health.

Suicidal ideation may be prevented by the intervention of professionals. In a short period of time, Bernard went through a car accident, a relationship break-up, and a fire on the farm. He described what type of social response made sense for him at that time:

The car was a total wreck, few days later the wife was gone with the children and my flock was down to ashes. At the fire, the policeman on the scene gave me his phone number. It meant, "You are in deep shit. Call me before you do anything stupid, like suicide." It shook me, so I sought help with a men's support group. It really helps me to connect with other people who are not into farming. (Bernard)

The intervention of this policeman is an illustration of a specific pattern of social support. When his wife left with the children, Bernard — and many participants in the same situation — did not receive much social support. But for the material crisis, the barn on fire, volunteer firefighters and the whole community rushed to help without asking. This highlights a disparity of solidarity in which social support is openly offered for a material crisis, but not for a personal crisis such as a break-up. Bernard explained that the break-up left deeper scars than the fire and the car accident.

What shook me the most was the break-up. Everything crashes, no more solid ground ... so I got lost in work, no real support from the people around me at this moment. (Bernard)

On a wider level, social responses are directly linked to the extent to which farmers' mental health is considered a social issue by political and farming authorities and health agencies. During data collection for this study, an interesting debate occurred at the Province of Quebec's National Assembly on a political response to farmers' psychological distress. When asked in the National Assembly whether the government was aware of the growing problem of psychological distress, and the mounting suicide rate, among Quebec farmers, the Minister of Health and Social Services answered that they were aware, because of newspaper articles. However, while acknowledging the seriousness of these issues, the Minister felt that anyone in Quebec in psychological distress should seek help from appropriate professionals (Assemblée Nationale du Quebec, 2012).

This exchange is meaningful in regard to the social representations of adversity faced by farmers. Adversity faced by farmers is reformulated as an adaptation problem, individualizing the situation without proposing any type of social and political responsibility. Barriers to access and social acceptability of mental health services remain completely neglected. 
International Journal of Child, Youth and Family Studies (2019) 10(1): 49-69

Meanwhile, despite lack of action by politicians, the practitioners and researchers in the focus groups were unanimous that there was an emerging grassroots movement in farming communities to raise awareness of, and to prioritize, the mental health and well-being of farming men and their families. Two promising community-based responses are highlighted here. The implementation of travailleurs de rang $^{3}$ [rural social workers] is a notable contribution in this direction. Rooted in generalist practice and with a rich knowledge of farming life, rural social workers intervene in many different ways: promoting farming's social recognition; supporting community sustainability; assisting in financial issues related to farming; and providing therapeutic services in group, family, and individual practice, including crisis intervention (Labrecque-Duchesneau, Gagné, \& Picard, 2011). These programs are mainly funded by local or regional communities.

The second community-based response is the adaptation of the Sentinelles ${ }^{4}$ [Gatekeepers] program to farming communities. Volunteers are trained to identify, contact, and accompany people in distress who are at risk of suicide to appropriate community services (e.g., shelter) or health and social services (e.g., hospital).

However, a social response to farmers' adversity may come from an unexpected source. The qualitative design of this study enabled a unique observation during data collection: the research process itself helped counter stigma and strengthen participants' sense of dignity. Many expressed their gratitude during and after interviews as they felt their voices were rarely heard in this way. This suggests that participants needed a better social acknowledgement of the burden they were facing and that they hoped their voices could make a difference.

In sum, two opposite trends emerge: social responses have both negative and positive impacts on farming men and their families. A negative impact is observed from the devaluing discourse of farming and from the response of political leaders to the crisis of farmers' high rates of psychological distress. On the other hand, a positive impact emerges from the awareness raised by advocacy and community-based initiatives to support farmers.

\section{Discussion}

This study aimed to bring a gender analysis of individual and social responses to adversity faced by farming men. It suggests that farming men are part of the global change in masculine identities and practices. Traditional masculinity seems to be losing its legitimacy to impose its standards on farming men, as with other groups (Anderson, 2009; Anderson \& McGuire, 2010; Brandth, 2016). Some results suggest change is happening through fathering practices, similar to other rural Canadian and Norwegian studies in which traditional masculinity is challenged by

3 https://ici.radio-canada.ca/nouvelle/1115039/des-travailleurs-de-rang-pour-soutenir-la-sante-psychologique-desagriculteurs

${ }^{4}$ https://www.aqps.info/aider/devenir-sentinelle.html 
International Journal of Child, Youth and Family Studies (2019) 10(1): 49-69

alternative or progressive configurations of practice (Brandth, 2016; Bye, 2009; Creighton et al., 2017). Gender transformation is salient in the individual responses to adversity by which farming men departed from practices aligned with traditional masculinity (i.e., denial, stoicism, social withdrawal) and chose to open up about their emotions and connect with family, friends, and professionals.

Examination of social responses highlights a wide range of practices, from devaluing of farming by a part of the population to individualization of farmers' issues by some politicians. This observation is global: farmers in Europe, North America, and Australia have responded to the devaluation of their occupation and lifestyle by promoting different versions of the same message: "no farmer no food" (Droz et al., 2014; Judd et al., 2006; Kennedy et al., 2014; McLaren \& Challis, 2009; Price, 2012; Roy et al., 2013). On the other hand, some politicians team up with farmers and members of farmers' communities to mobilize, raising awareness of the adversity faced by farmers, taking action, and advocating. Farming communities respond to high rates of distress and suicide by tightening the social net with innovative strategies like the Gatekeepers program and rural social workers. The Gatekeepers program has been highlighted as one of the strategies with the strongest proof of success in preventing suicide in rural communities (NHS Health Scotland, 2013). The ongoing Gatekeepers project in the Province of Quebec started only in 2016, so evidence of success is not yet available. The rural social worker program started in 2011 and an evaluation of the program suggests positive results, notably on destigmatizing help-seeking and providing a proactive outreach to those people less likely to engage with professional services (Viens \& Lebeau, 2012).

Globally, there is evidence that mental health services and information, along with mental health literacy, require further attention to effectively reach farming men and their families (Alston, 2012; Garnham \& Bryant, 2014; Kennedy et al., 2014; National Centre for Farmer Health, 2016; Prévitali, 2015; Roy et al., 2013). This represents an important challenge for mental health promotion especially in the area of stigma reduction. In terms of direct intervention, farmers' helplines have been implemented in Australia, Canada, and France, a response that facilitates both access and social acceptability. Our participants' discourse aligns with the idea that, at the community level, a sense of belonging and social support are key protective factors against mental health problems such as depression, anxiety, and suicide (McLaren \& Challis, 2009; Price \& Evans, 2009; Roy, Tremblay, \& Robertson, 2014).

\section{Recommendation for Research and Practice}

We offer some recommendations for both future research and practice. Results suggest that when a farmer faces adversity, there is a critical opportunity to question and deconstruct the restrictive and rigid alignment with traditional masculinity that is connected with negative health and well-being outcomes. Deconstructing those aspects of traditional masculinity should not be attempted without also promoting the strengths and benefits of more open and inclusive masculinities. As such, restrictive masculine norms dictating men's mental health practices (i.e., 
International Journal of Child, Youth and Family Studies (2019) 10(1): 49-69

stoicism and excessive self-reliance) need to be redefined in order to position help-seeking as a human, positive, and rational response to adversity. The ambivalence and resistance towards traditional masculinity described by participants can be used to leverage interventions and social change. It may be used to challenge and extend the idea of what it means to be or act like a man in regard to health practices (e.g., questioning the ideas that help-seeking is womanly or that men do not get depressed). It may be seen as a small step towards the deconstruction of the binary, homogeneous, and mutually exclusive vision of gender. While the present study focused on stressrelated coping, a few participants brought the conversation towards sexual orientation and changes in gender identity over time. Future research can focus on these topics in greater detail.

On a more global scale, in the context of modern farming, serious questions are raised about the psychosocial impacts of the neoliberal economy. The crisis of farmers' high rates of psychological distress is actually worsened by an aggressive neoliberal approach to mass production that is causing many farmers to operate at a loss (Hunt, Rosin, Campbell, \& Fairweather, 2013), imposing adverse living conditions that cannot be reduced to farmers' individual psychological issues. This situation is addressed in a study that elucidates the psychological impacts of farming policies in Switzerland, France, and the Province of Quebec in Canada (Droz et al., 2014). In Canada, voices have been raised among farming organizations to defend the family-owned, human-scale farming business, as opposed to mass production. Thus, promoting farmers' mental health and well-being requires social justice work at every level: individual, collective, social, and political.

Implementation and assessment of programs based on recognized practice such as Gatekeepers and rural social workers are promising avenues that must be pursued. Given the high suicide rates in farming populations, bereavement programs such as Australia's "Ripple Effect" are likely to help farming men open up about their experiences and to reduce isolation and stigma (National Centre for Farmer Health, 2016). Priority should also be given to advocacy for farming communities' well-being, including support for crisis response and prevention programs at local and national levels. Accordingly, more investigation is needed regarding social responses by communities and by the health and political authorities who have the power to legitimate (or not) adversity faced by farmers as a social issue and to provide resources for appropriate and innovative responses. Finally, development of male-friendly practice should capitalize on the value of solidarity beyond its material dimension to include personal crisis as a circumstance that calls for solidarity.

\section{Conclusion}

The aim of this paper is to highlight adversity faced by farming men as a serious social issue and to offer new perspectives on social and individual responses to that adversity through a response-based and gender-transformative analysis. Some limitations must be considered. As with any qualitative study, generalization is not possible. Those farming men who were the most 
reluctant to open up might not have responded to the invitation to participate in the study as frequently as others would who were questioning and resisting traditional masculinity. Also, faceto-face interviews raise the issue of social desirability bias. The strategies that the interviewer used to counter social desirability bias were to mention that there are no right or wrong answers and to welcome different points of view verbally and non-verbally.

Despite these limitations, the study offers an innovative approach to better understanding the interaction between gender, place, and occupation in the context of farming men facing adversity. Farming men are active in the transformation of masculinities by questioning their own social practices and by assuming an open resistance to restrictive, unequal aspects of traditional masculinity. These acts of resistance are echoed in individual responses such as negotiating gender practices and relations and in social responses in the form of social support from families, communities, health services, and political advocacy. Combining response-based practice with gender-transformative health promotion sheds a new light on the lives of farming men; furthermore, it sparks new questions about other marginalized groups in rural settings like farming women or non-farming rural residents. Farming and, more widely, rurality are complex and diverse realities and more work is needed to distil contexts of privilege and marginalization, and oppression and resistance. Finally, the words of a participant, Jean-François, are relevant to inspire reflection for future research, advocacy, and practice. After the interview, he explained why academic responses to farmers' adversity matters: “It's great because you [the interviewer] don't come from a farming background and yet you show interest not only for what we live but what we think. It's rare and important." 
International Journal of Child, Youth and Family Studies (2019) 10(1): 49-69

\section{References}

Alston, M. (2012). Rural male suicide in Australia. Social Sciences \& Medicine, 74(4), 515-522. doi:10.1016/j.socscimed.2010.04.036

Anderson, E. (2009). Inclusive masculinity: The changing nature of masculinities. New York, NY: Routledge.

Anderson, E., \& McGuire, R. (2010). Inclusive masculinity theory and the gendered politics of men's rugby. Journal of Gender Studies, 19(3), 249-261.

doi:10.1080/09589236.2010.494341

Assemblée Nationale du Québec. (2012). Journal des débats du 12 mai 2012: 39e législature, $2 e$ session [Journal of debates on May 12, 2012: 39th legislature, 2nd session] (Vol. 42, no. 110). Quebec City, QC: Author. Retrieved from http://www.assnat.qc.ca/fr/travauxparlementaires/assemblee-nationale/39-2/journaldebats/20120522/59369.html\#_Toc325543987

Barker, G., Ricardo, C., Nascimento, M., Olukoya, A., \& Santos, C. (2010). Questioning gender norms with men to improve health outcomes: Evidence of impact. Global Public Health, 5(5), 539-553. doi:10.1080/17441690902942464

Beaulieu, M. (2015). Demographic changes in Canadian agriculture. Ottawa, ON: Statistics Canada.

Boisvert, K. (2009, October 14). La colère gronde chez les agriculteurs du Quebec [Growing anger among Quebec's farmers]. 24h. Retrieved from http://bit.ly/2ET3LA8

Boisvert, S. (2017). Les masculinités télévisées et les paradoxes contemporains du genre : Une analyse comparative des identités narratives dans les fictions sérielles nord-américaines (Quebec, Canada, États-Unis) [Television masculinities and contemporary paradoxes of the genre: A comparative analysis of narrative identities in North American serial fiction (Quebec, Canada, United States)] (Doctoral dissertation). University of Quebec at Montreal, Montreal, QC. Retrieved from http://www.archipel.uqam.ca/9686/

Bourke, L., Humphreys, J. S., Wakerman, J., \& Taylor, J. (2010). From 'problem-describing' to 'problem-solving': Challenging the 'deficit' view of remote and rural health. Australian Journal of Rural Health, 18(5), 205-209. doi:10.1111/j.1440-1584.2010.01155.x

Brandth, B. (2016). Rural masculinities and fathering practices. Gender, Place \& Culture, 23(3), 435-450. doi:10.1080/0966369X.2015.1013454

Bye, L. M. (2009). 'How to be a rural man': Young men's performances and negotiations of rural masculinities. Journal of Rural Studies, 25(3), 278-288.

doi:10.1016/j.jrurstud.2009.03.002 
International Journal of Child, Youth and Family Studies (2019) 10(1): 49-69

Campbell, H., Mayerfeld Bell, M., \& Finney, M. (Eds.). (2006). Country boys: Masculinity and rural life. University Park, PA: Pensylvania State University Press.

Canadian Agricultural Safety Association. (2005). National stress and mental survey of Canadian farmers. Winnipeg, MB: Author. Retrieved from https://www.casaacsa.ca/download/national-stress-and-mental-survey-of-canadian-farmers/

Coates, L. (2016, May). Responding to victims of violent crime: Mutualizing. Paper presented at Responses Matter: Responses to Interpersonal Violence (Network Meeting and Conference), Montreal, Quebec.

Connell, R. W., \& Messerschmidt, J. W. (2005). Hegemonic masculinity: Rethinking the concept. Gender \& Society, 19(6), 829-859. doi:10.1177/0891243205278639

Courtenay, W. H. (2006). Rural men's health: situating risk in the negociation of masculinity. In H. Campbell, M. Mayerfeld Bell, \& M. Finney (Eds.), Country boys: Masculinity and rural life. University Park, PA: Pensylvania State University Press.

Creighton, G., Oliffe, J., Ogrodniczuk, J., \& Frank, B. (2017). "You've gotta be that tough crust exterior man": Depression and suicide in rural-based men. Qualitative Health Research, 27(12), 1882-1891. doi:10.1177/1049732317718148

Droz, Y., Miéville-Ott, V., Jacques-Jouvenot, D., \& Lafleur, G. (2014). Agriculture familiale et santé publique: Une anthropologie comparée des politiques agricoles francophones: France-Québec-Suisse [Family farming and public health; a comparative anthropology of francophone farming policies: France-Province of Quebec-Switzerland]. Paris, France: Karthala.

Fraser, C. E., Smith, K. B., Judd, F., Humphreys, J. S., Fragar, L. J., \& Henderson, A. (2005). Farming and mental health problems and mental illness. International Journal of Social Psychiatry, 51(4), 340-349. doi:10.1177/0020764005060844

Garnham, B., \& Bryant, L. (2014). Problematising the suicides of older male farmers: Subjective, social and cultural considerations. Sociologia Ruralis, 54(2), 227-240. doi:10.1111/soru.12029

Gough, B. (2013). The psychology of men's health: Maximizing masculine capital. Health Psychology, 32(1), 1-4. doi:10.1037/a0030424

Haggerty, J., Campbell, H., \& Morris, C. (2009). Keeping the stress off the sheep? Agricultural intensification, neoliberalism, and 'good'farming in New Zealand. Geoforum, 40(5), 767777. doi:10.1016/j.geoforum.2008.12.003 
International Journal of Child, Youth and Family Studies (2019) 10(1): 49-69

Hunt, L., Rosin, C., Campbell, H., \& Fairweather, J. (2013). The impact of neoliberalism on New Zealand farmers: Changing what it means to be a 'good farmer'. Extension Farming Systems Journal, 9(1), 34.

Jacques-Jouvenot, D., \& Laplante, J.-J. (2009). Les maux de la terre : Regards croisés sur la santé au travail en agriculture [Land's pain: Perspectives on workers' health in agriculture]. La Tour d'Aigues, France: Editions de l'Aube.

Judd, F., Jackson, H., Fraser, C., Murray, G., Robins, G., \& Komiti, A. (2006). Understanding suicide in Australian farmers. Social Psychiatry and Psychiatric Epidemiology, 41(1), 1-10. doi:10.1007/s00127-005-0007-1

Kennedy, A. J., Maple, M. J., McKay, K., \& Brumby, S. A. (2014). Suicide and accidental death in Australia's rural farming communities: A review of the literature. Rural Remote Health, 14(1), 2517.

Labrecque-Duchesneau, M., Gagné, J., \& Picard, F. (2011). Le travailleur de rang: Une plusvalue pour une qualité de vie en milieu rural [Rural workers: For a better quality of life in rural areas]. Intervention, 135(2), 106-114.

Lafleur, G., \& Allard, M.-A. (2006). Enquête sur la santé psychologique des producteurs agricoles du Québec [Study on Quebec farmers' psychological health]. Montreal, QC: COOP Fédérée.

Lamothe, J. (2016, October 14). Baisse des revenus, suicides : La crise des agriculteurs « fait beaucoup moins de bruit que l'affaire Alstom » [Income decrease, suicide: Farmers' crisis "raises less attention than the Alstom's controversy"]. Le Monde. Retrieved from http://lemde.fr/2dRhP1u

Levant, R. F., \& Habben, C. (2003). The new psychology of men: Application to rural men. In B. H. Stamm (Ed.), Rural behavioral health care: An interdisciplinary guide. (pp. 171-180). Washington, DC: American Psychological Association.

Magnin, L., Chappuis, M., Normand, G., Pereira, B., Lezé, S., \& Lesens, O. (2017). Health issues and mental distress in French active farmers: A quantitative and qualitative study. International Journal of Environmental \& Agriculture Research, 3(9), 12-22.

McLaren, S., \& Challis, C. (2009). Resilience among men farmers: The protective roles of social support and sense of belonging in the depression-suicidal ideation relation. Death Studies, 33(3), 262-276. doi:10.1080/07481180802671985

National Centre for Farmer Health. (2016). The Ripple Effect. Retrieved from https://therippleeffect.com.au/ 
International Journal of Child, Youth and Family Studies (2019) 10(1): 49-69

NHS Health Scotland. (2013). National guide on suicide prevention in rural areas. Part 2: Reference document. Evidence-based approach and case study examples. Edinburgh, Scotland: Author. Retrieved from http://www.healthscotland.com/uploads/documents/21002National\%20Guide\%20to\%20Suicide\%20Prevention\%20in\%20Rural\%20Areas\%20Part\%2 02.pdf

Oliffe, J. L., \& Mroz, L. (2005). Men interviewing men about health and illness: Ten lessons learned. Journal of Men's Health and Gender, 2(2), 257-260.

Parent, D., Perrier, J.-P., \& Rousseau, G. (2010). Analyse de l'isolement social, de la sociabilité et de la qualité du soutien social chez les jeunes agriculteurs québécois [An analysis of social isolation, sociability and the quality of social support among young farmers in Quebec]. Quebec City, QC: Laval University/Traget Laval.

Pleck, J. H. (1995). The gender role strain paradigm: An update. In R. F. Levant \& W. S. Pollack (Eds.), A new psychology of men (pp. 11-32). New York, NY: Basic Books.

Prévitali, C. (2015). Les conditions du suicide des professionnels agricoles [Suicide conditions of farming professionals]. Pensée Plurielle, 1(38), 105-121.

Price, L. (2012). The emergence of rural support organisations in the UK and Canada: Providing support for patrilineal family farming. Sociologia Ruralis, 52(3), 353-376. doi:10.1111/j.1467-9523.2012.00568.x

Price, L., \& Evans, N. (2009). From stress to distress: Conceptualizing the British family farming patriarchal way of life. Journal of Rural Studies, 25(1), 1-11.

doi:10.1016/j.jrurstud.2008.03.008

Qin, Q., Jin, Y., Zhan, S., Yu, X., \& Huang, F. (2016). Suicidal ideation among rural immigrant daughters-in-law with multi-roles as females, farmers and immigrants in China. Psychology, Health \& Medicine, 21(5), 608-617. doi:10.1080/13548506.2015.1112414

Richardson, C., \& Wade, A. (2016). Center for response based practice. Retrieved from http://www.responsebasedpractice.com/

Robertson, S. (2008). Theories of masculinities and men's health-seeking practices. Nowhere man's press. Retrieved from http://man-ni.org/resources/stevespeech.pdf

Robertson, S., Elder, K., \& Coombs, R. (2010). Rural men's mental health. In D. Conrad \& A. White (Eds.), Promoting men's mental health (pp. 57-73). Oxford, UK: Radcliff.

Roy, P., \& Tremblay, G. (2015). L'expérience du stress chez les agriculteurs: Une analyse du genre masculin [Farmers experiencing stress: A gender analysis]. Nouvelles pratiques sociales, 27(2), 236-252. doi:10.7202/1037690ar 
International Journal of Child, Youth and Family Studies (2019) 10(1): 49-69

Roy, P., Tremblay, G., Oliffe, J. L., Jbilou, J., \& Robertson, S. (2013). Male farmers with mental health disorders: A scoping review. Australian Journal of Rural Health, 21(1), 3-7. doi:10.1111/ajr.12008

Roy, P., Tremblay, G., \& Robertson, S. (2014). Help-seeking among male farmers: Connecting masculinities and mental health. Sociologia Ruralis, 54(4), 460-476. doi:10.1111/soru.12045

Roy, P., Tremblay, G., Robertson, S., \& Houle, J. (2015). “Do it all by myself”: A salutogenic approach of masculine health practice among farming men coping with stress. American Journal of Men's Health, 11(5). 1536-1546. doi:10.1177/1557988315619677

Savoie-Zajc, L. (2003). L'entrevue semi-dirigée [The semi-directed interview]. In B. Gauthier (Ed.), Recherche sociale: de la problématique à la collecte de données [Social research: From the problem to data collection] (pp. 293-316). Quebec City, QC: Presses de l’Université du Québec.

Sturgeon, R., \& Morrissette, P. J. (2010). A qualitative analysis of suicide ideation among Manitoban farmers. Canadian Journal of Counselling and Psychotherapy, 44(2), 191-207.

Tannenbaum, C., Greaves, L., \& Graham, I. D. (2016). Why sex and gender matter in implementation research. BMC Medical Research Methodology, 16(1), 145. doi:10.1186/s12874-016-0247-7

Thomas, D. R. (2006). A general inductive approach for analyzing qualitative evaluation data. American Journal of Evaluation, 27(2), 237-246. doi:10.1177/1098214005283748

Viens, C., \& Lebeau, A. (2012). Bilan factuel du projet Travailleur de rang et points de vue des partenaires concernés [Report on project Travailleur de rang and partners' point of view]. Longueil, Quebec: Agence de la santé et des services sociaux de la Montérégie; Direction de santé publique; Au coeur des familles agricoles (ACFA).

Wang, C.-W., Chan, C. L. W., \& Yip, P. S. F. (2014). Suicide rates in China from 2002 to 2011: An update. Social Psychiatry \& Psychiatric Epidemiology, 49(6), 929-941. doi:10.1007/s00127-013-0789-5 